\title{
Developing Primary EFL Students' Multiliteracies Competence Through Drama Teaching: A Case Study in China
}

\author{
Yuanyuan Chen ${ }^{1,2}$ \\ ${ }^{1}$ Education Group, Guangdong University of Foreign Studies, Guangzhou, China \\ ${ }^{2}$ School of English Education, Guangdong University of Foreign Studies, Guangzhou, China
}

Email address:

yychen@gdufs.edu.cn

\section{To cite this article:}

Yuanyuan Chen. Developing Primary EFL Students' Multiliteracies Competence Through Drama Teaching: A Case Study in China. International Journal of Literature and Arts. Special Issue: Humanity and Science: China's Intercultural Communication with the Outside World in the New Era. Vol. 8, No. 2, 2020, pp. 46-51. doi: 10.11648/j.ijla.20200802.13

Received: February 27, 2020; Accepted: March 10, 2020; Published: March 31, 2020

\begin{abstract}
Multiliteracies competence has emerged as an important research field, yet it remains a great challenge for primary EFL teachers in China to develop students' multiliteracies competence. With the implementation of educational reform in K12 education in China, the importance of cultivating multiliteracies competence for primary school students has become increasingly prominent. Meanwhile, in the current K12 education curriculum in China, the practice of offering English drama courses caters to the needs of enhancing students' multiliteracies competence. This qualitative study aims to exlore: (1) how are dramas taught in primary EFL classes in China? (2) how is students' multiliteracies competence developed through learning drama? The participant of this longitudinal narrative inquiry is an EFL teacher at a primary school in Southern China. Data include two-semester-long observation of the English drama classes in the school, weekly meetings on drama teaching, workshops with foreign drama experts and interview narratives, as well as documents such as the participants' lesson plans, journals and students' feedback. Findings show that EFL drama teaching in the primary school adopts multiliteracies pedagogy, drawing on a range of media and aiming to develop students' all-around skills. Findings also reveal that students' language competence and multiliteracies competence are indeed greatly enhanced through drama teaching and learning. Implications for further teacher development are discussed, including offering English drama education in pre-service programs, enhancing acting skills mentoring in internship and in-service training, and observing and reflecting on one's own and their peers' drama teaching practices and raising their multiliteracies awareness and intercultural awareness.
\end{abstract}

Keywords: Multiliteracies Competence, Multimodality, Drama Teaching, Primary EFL Student

\section{Introduction}

With the gradual advancement and deepening of the reform of college entrance examination and the implementation of core academic literacy, there is also a trend of foreign language teaching reform in K12 education in China. EFL teaching focuses more on developing students' competence in language use, cultural awareness, critical thinking and learning ability, aiming to guide students to understand the real world in a multimodal environment, understand various experiences and construct their own values on the real world. According to Zhu [1], it's vital to "enhance students' awareness of creative learning in multimodal environments, promote critical thinking and logic reasoning, help them understand virtual reality and design images and audiovisual files that simulate reality, do scientific simulations which make it possible to create virtual multimedia, such as various scenes, to change the traditional teaching scenarios and achieve more positive results". Classroom teaching has gradually changed from chalk-and-blackboard mode to multimodal environment, in which multimedia and AR / VR technology are widely used, particularly in EFL classes. Under the circumstances, how to cultivate primary students' multiliteracies competence to adapt to the digital and information age has become an urgent task.

This study, drawing on classroom observations and the 
participant' interview narratives, based upon the case in a foreign language school (W School) in Guangzhou, China, examines how the drama course is carried out and how the students' multiliteracies competence is developed through the drama course.

So the study aims to answer the question: How do drama courses help promote primary students' multiliteracies competence in the Chinese educational context? To be specific, the study explores the following two questions:

1) How are dramas taught in primary EFL classes in China?

2) How is students' multiliteracies competence developed through learning drama?

\section{Literature Review}

\subsection{Multiliteracies Pedagogy}

In September 1994, The New London Group [2] proposed the concept of multiliteracy and multimodality. Multiliteracies pedagogy is an approach introduced in response both to the rapidly increasing cultural and linguistic diversity of students in many 'receiving' countries and to the sophisticated communication technologies in use in the twenty-first century. Through its focus on multimodality, multiliteracies pedagogy acknowledges the range of modes of meaning-making and communication (audio, visual, linguistic, spatial, performative etc.) extending language and literacy education beyond traditional literacy practices.

In 2009, the New London Group members, Cope and Kalantzis [3] argued: "Traditional literacy does not by and large recognize or adequately use the meaning and learning potentials inherent in different modes, and the synaesthesia involved in shifting between one mode and another. Rather, it tries to confine itself to the monomodal formalities of written language, as if the modality of written language could be isolated as a system unto itself."

Ntelioglou [4] proposed that "multiliteracies pedagogy advocates for situated practice (a term coined by the New London Group 1994), which involves the provision of innovative learning environments that create opportunities for students to engage in meaningful experience, making use of their own life experiences." The New London Group's research was heavily influenced by Kress and Leeuwen [5-7], and subsequent studies included criticism on research in critical linguistics and multimodal discourse analysis.

Apart from the definition from the New London Group, there are multiple definitions of multiliteracies competence. Williamson [8] pointed out that multiliteracies competence refers to the ability to present information in multimedia and multimodalities. This ability is considered to consist of the following five components: 1) linguistic component; 2) visual component; 3) audio component; 4) posture (gestural) component; 5) spatial component. $\mathrm{Hu}$ [9] thinks that it can be divided into the following four levels: 1) learning participants should be able to effectively use information technology to solve their problems; 2) participants can use information technology to retrieve information, have a variety of multimodal reading and writing abilities (such as printed materials, pictures, photos, music, etc.); 3) participants can effectively use the online information; 4) participants can give information on the current situation of the Internet ecology and information technology use in society. Diversified literacy includes, but is not limited to, traditional language reading skills. It contains human multimodal learning systems, including what Suhor [10] called "media transformation" (multimediation); that is, replacing one ideographic system with another.

In recent years, more and more attention has been paid to multimodal teaching research at home and abroad. Many researchers have extensively studied language teaching in multimodal contexts. And among them, Gu [11] demonstrated on how to do multimodal research by using his "Character Modeling Language" Model. And he further proposed five hypotheses on learning languages with multimedia based upon cognitive psychology. Zhang [12] proposed "A Comprehensive Theoretical Framework for Multimodal Discourse Analysis", which incorporated culture, context, meaning, form, and media. Multimodal pedagogies proposed by Stein [13] have provided a strong theoretical basis for this study. The cultivation of multiliteracies ability in multimodal teaching of drama English is more and more important.

There is also some research in multiliteracies and multimodality in EFL teaching and learning practice. Liu [14] pointed out that EFL teachers need to create multi-modal and positive learning activities based on the teaching objectives and content, with the help of different forms of pictures, sounds, and images, and with due attention to students' language communication skills and cross-cultural communication skills. Thus teachers can cultivate and provide students with a near-natural learning and communication environment, so that students can really improve the practical use of language and communication skills. Huang [15] believes that teachers themselves should change the traditional teaching method by implementing multiliteracies pedagogy.

\subsection{Drama Education}

Drama means action or play and it can date back to Ancient Greek. According to Kao \& O’Neill [16], "Drama is contextual, and it creates a social world within the target language in authentic interactions.

Communication context, social language or drama and active participation are considered indispensable factors of drama and language." And as Bolton [17-19] and Neelands [20] argued, drama education is an activity in which the teacher and students invent and enact dramatic situations for themselves rather than for an outside audience. This activity, perhaps most widely known as drama education, has also been called classroom drama. And as Booth [21], Edmiston and Enciso [22] and Wilhelm [23] argued, drama education has the potential to extend language and literacy education in mainstream language classroom and Byram and Fleming [24] and Culham [25] advocate that it also can help in the second language classroom, with its situated and contextual features 
in the social world.

According to Holden [26], educational drama or drama in education means applying drama in teaching and acquiring subject knowledge through drama. Educational drama involves acting, expressing feelings in the teaching process, together with the learners' development of language competence, cognitive competence and the interactive competence.

According to Mackey and Morrison [27], Nicholson [28] and Davis [29], "the rise of standardisation and instrumental agendas in education can make it difficult to maintain a place for drama in the curriculum and that has been particularly the case in the UK, home to many of the early pioneers in drama education. However, "rapid growth has occurred in some regions, for example in some Asian countries [30], where the introduction of drama and applied theatre approaches have often been linked to agendas to cultivate innovation and creativity [29].

In the past two decade, K12 education in China has been attaching more focus on drama courses and/or drama clubs based upon the concept of interdisciplinary and holistic education. At the same time, the bottom-up practice has also been advocated by the government. As Kavakli [31] argues, drama teaching helps develop students' innovative ability, problem-solving competence, communication skills and empathy as well as positive attitudes like self-trust and confidence.

\section{Research Methodology}

\subsection{Research Site and Participants}

W Primary School was chosen as my research site because of two reasons. First, two teachers were my former students in G University. I had built up trustworthy relationships with them, which in qualitative research proves to be vital (Connelly \& Clandinin, 2006; Chen, 2004) [32-33]. Second, W School has started its initiative in drama teaching ever since 2017, which is obviously a pioneer in the district. And the students in W School are known for their outstanding performance in English proficiency and drama.

The school initiated an optional drama course to the third and fourth graders every Thursday afternoon in 2016. And as early as 2014 the school started its first drama contest in order to encourage the students to develop their performance skills and language proficiency, which echoed with the school's motto to cultivate students with international awareness through various activities [26]. Ever since then, almost all the English teachers in the school work together as the drama teaching team, and studied on teaching pedagogy, together with training from experts in drama education and multiliteracies pedagogy. With three years' teaching and research practice, a school-based teaching curriculum was set up, and the school officially incorporated English drama teaching into its curriculum in 2017 and the drama course became a school-based subject for students from the first graders to the sixth graders. With course consultancy and assessment from drama education experts and professors, discreet and serious selection of dramas and scripts together with repeated research on teaching pedagogy and learning from other schools and symposiums on dramas, the school finally officially took the initiative of teaching English drama to primary students [34].

In this research, the student participants were fifth graders from the school, who had learned English for at least four years. Since the drama teaching reform was mandatory in $\mathrm{W}$ School, with a greatly increased workload in class preparation, teachers have had a long and hard time overcoming the difficulties. The teacher participant Miss Jenny had been in the teaching profession for over ten years and joined the drama course since 2016. In addition, Miss Jenny was the English team leader of Grade five, and head teacher of the student participants. The dramas were selectively chosen, and the scripts were kept original with minor adaptation to facilitate students' understanding, with the guidance of overseas teachers from North America.

\subsection{Data Collection}

I observed the participating class from September 12th, 2018 to June $10^{\text {th }}, 2019$, which covered two semesters, including the classes in the classroom and the demo classes in the school auditorium, as well as the drama shows held by the school and the university. The data collected include class observation and interview narratives of the participating teacher, journals from students as well as pictures together with videotapes and documents from the school etc. Certificates of honor and awards, together with documents were all together provided for triangulation. There were 43 students in the participating class. I took class observation notes, took interviews with the teacher, had a brief interview with the vice principal who was held responsible for drama teaching and collected eight journals from the students.

\subsection{Data Analysis}

The multiliteracies pedagogy [2] was adopted in the drama class, in which the class design engages four elements, namely situated practice, overt instruction, critical framing and transformed practice. And the Grounded Theory [35] was adopted for data analysis. The classroom observation notes and interview narratives together with other data were transcribed word-to-word and were sent back to the participating teacher for double-check.

\section{Results and Discussions}

\subsection{The EFL Drama Teaching Practice Based on Multiliteracies Pedagogy}

The course has been carried out for six semesters so far. Based on the classroom observation, the teaching group, particularly the participating teacher Jenny has conducted the course upon the multiliteracies pedagogy, involving situated practice, overt instruction, critical framing and has obtained transformed practice to some extent. Here is the description of 
a demonstration class with the topic Pinocchio.

First, the students previewed the story and prepared before class. Students surveyed and collected materials as well as made some props before class about the story Pinocchio. Meanwhile, the teacher carefully studied the story and made teaching plans centered upon the multiliteracies pedagogy. Then, it came to the classroom teaching. The teaching objectives were: by the end of the class, the students would be able to know the expressions about telling lies, being honest etc; they would also be able to enhance their pronunciation and intonation in dialogue and develop acting skills of mirroring; and they would be able to develop interest in learning and performing dramas.

When it came to the class, the teacher first described a scenario of kids telling lies which evoked heated discussion on what would happen as a consequence. Then the students were encouraged to perform or retell stories such as The Boy Who Cried Wolves in groups. Through this step the students' memory and interest were activated. Then, the students were advised to read the story Pinocchio with the teacher's scaffolding on vocabulary and language points. After that, the students were required to brainstorm on how to use the resources in classroom to perform the story, focusing on telling lies and experience punishment. They were challenged with two questions: if you were Pinocchio, what would you do differently? Why? How are you going to make your acting impressive? Each group rehearsed briefly and the teacher Jenny walked around, observing different groups and giving advice. One group was chosen to perform and suggestions from other groups were encouraged. Finally assignments about performing the story in groups after school were given, which would be first thing to do the next time.

In the above drama class, the first and second steps of class design is in line with the multiliteracies pedagogy, namely "situated practice" and "overt instruction". Then the video and brainstorming part starts from the perspective of the title, "Pinocchio", aiming to guide students to analyze all aspects of language, culture related to telling lies as well as to make use of all possible multimedia and props to perform. During this process the teacher provided scaffolding for the students with pictures and word bank, so that students can realize not only verbal language, but also sounds, images, and facial expressions, body language, etc. are all important for facilitating understanding. This step echoes with the third step in the theory of multiliteracies teaching, namely, "overt instruction". Third, students start learning the lines and the story. This is the key step and preparation for drama performing, language output and oral interaction. And this part echoes with the "situated practice" and "critical framing". Fourth, the performance practice part involves both the teacher and students to explore the story, characters, feelings, meaning making, performing with appropriate body language, emotion etc. This section is in line with the final part in multiliteracies theory, namely "transformed practice"[2].

Based upon the class, it's found that three layers of multiliteracies enhancement have been achieved, namely the enhancement of teacher's mulitiliteracies competence, the students' multiliteracies competence, and the assessment of multiliteracies competence by both the teacher and the peer students. First, the teacher uses multimodal and multiliteracies means and skills to carry out the class. And the teachers were observed upon whether they use multimedia resources reasonably and appropriately. That is, whether they made it possible to help students obtain and process valid information and get the appropriate skills in performing English drama. Second, by drawing on the multimodal resourse offered by the teacher and environment, students perform the drama and do further study on the drama in terms of rewriting and critical thinking. Third, teachers and students would work together to evaluate and self-evaluate on enhancement in their own multiliteracies competence in drama performing before, during and after class.

\subsection{Enhancement of Students' Multiliteraices Competence in Drama Learning}

The classroom observation notes and interviews demonstrate that the drama course is highly welcomed by the students and club participants. And their multiliteracies competence has been greatly improved and multiliteracies awareness has also been enhanced as well.

As the teacher Jenny said,

It's not easy for either the teachers nor the students to study drama and learning acting, because we the teachers are not professionals. We have been used to teaching students textbooks, vocabulary, grammar and how to do well in the exams. Drama is totally new for us. I had no idea what I can do to prepare for the class, what the curriculum is and what we need to learn to teaching the students. Luckily for me, I am extroverted and love dancing and singing. So although I didn't know about drama, I was bold enough to learn from the experts and consultant our school invited for us. At the beginning, my colleagues and I learned the ABCs about drama, and joined the workshops in and out of the school. I felt it really interesting to act, because I can totally relax and feel at ease when doing some ensemble exercises with the other teachers in the team. And learning to act is very fun, we could use both verbal language and body language to express ourselves, together with facial expressions and eye contact. I think it's miraculous to perform and feel like I'm talking to myself in a new way. Maybe that's why the artists are more sensitive and look different from the rest of us?

From the teacher's accounts, it's found that the teacher's awareness of multiliteracies has been greatly enhanced, accompanied by raised awareness of culture and art.

And student A narrated that,

It's so fun to take the drama class, because we don't follow the traditional way of taking classes. In the drama class, we listen to the teacher, observe the actors and actresses in the videos, read the scripts or stories, and perform the dramas together with our classmates. We can speak in an exaggerated tone, perform in our special way according to our own understanding, use hand-made props and there is no correct or wrong answer. I feel really relaxed in the drama class.

It's found that students have developed a sense of 
multiliteracies, in terms of visual, audio and oral resources. Besides learning the language itself, the students can develop their sense of using different media. And also as student B said,

I really enjoy the part when every group has the chance to perform and comment on each other's performance. Because everyone has their own understanding and it's really surprising to see how different and creative we could be in the class. When we perform the same story, we may have different understanding and hold different feelings. We sometimes won't directly give comments but perform in our way so each group could see who is doing better and improve in their performance later. It's far more interesting to take the drama class than to take the traditional classes. If possible, I hope we could have two or three a week instead of only one. I know a lot of my classmates hold the same opinion with me.

It's shown that the drama course is highly welcomed and students have not only developed a sense of multiliteracies in performing but also in assessment. The way students perform and do peer assessment and the way the teacher teaches is a good demonstration of multiliteracies pedagogy, involving various media and resources in classroom teaching and diversified ways of assessment throughout the course. As an important intermediary of English language learning, the drama course provides space for students to develop their language proficiency, multiliteracies competence, acting skills as well as their cultural awareness and intercultural awareness.

\section{Conclusion}

In this study, we have examined how the primary EFL students' multiliteracies competence is developed and enhanced through drama courses in Chinese educational context, by exploring how the drama course is carried out and how the students' multiliteracies competence is enhanced in the multimodal context. we were greatly encouraged to see that multiliteracies competence and multimodality in EFL teaching context have been attached more importance to and that drama teaching and learning has been taken as an indispensable and ever-increasingly important course in China in K12 education, just like western countries like US and UK. Besides, drama teaching and learning has promoted primary students' multiliteracies competence and multimodal awareness, at least in the participating school.

However, we also found that the participating school and the participants faced great challenges in teaching and learning drama. For example, they are non-drama majors, lack of professional guidance and education background, which is commonplace in Chinese schools that have also started English drama education. In our perspective, the EFL teachers still need teaching and training support from the school and municipal administration, like professional training, guidance from experts, cooperation with and support from colleagues from other subjects, such as music, dance, painting, opera arts, information technology and psychology etc. Besides, the teachers should be encouraged to see themselves as pioneers of drama teaching and researching in the profession. With a more interactive and encouraging platform, the enhancement of students' multiliteracies and multimodality awareness in drama teaching can be greatly improved.

\section{Acknowledgements}

This research is financially supported by the project " $A n$ Empirical Study on University Teachers' Teaching Engagement and Its Influence on Their Professional Development" granted by National Social Science Foundation of China in Education (Grant No. BIA180186). The support is gratefully acknowledged. We are also grateful for the participating teacher's support for our study. And our gratitude goes to the two anonymous reviewers for their invaluable feedback and suggestions.

\section{References}

[1] Zhu, Y. (2008). Research on Multiple Literacy and Its Enlightenment to China's Teaching Reform. Foreign Language Studies, (2).

[2] The New London Group. (1996). A pedagogy of multiliteracies: Designing social futures. Harvard Educational Review, 66: 60-92.

[3] Cope, B., and M. Kalantzis.(2009). A grammar of multimodality. The International Journal of Learning, 12, no. 2 $361-425$.

[4] Ntelioglou, B. (2011). "But why do I have to take this class?" The mandatory drama-ESL class and multiliteracies pedagogy. Research in drama education: The Journal of Applied Theatre and Performance, 595-615.

[5] Kress, G., \& Van Leeuwen, T. (1996). Reading Images: The Grammar of Visual Design. London: Routledge.

[6] Kress, G. (1997). Visual and verbal modes of representation in electronically mediated communication: The potentials of new forms of text. In Page to screen: Taking literacy into the electronic era, ed. I. Snyder, 53-79. St. Leonards, Australia: Allen \& Unwin.

[7] Kress, G., \& van Leeuwen, T. (2001). Multimodal Discourse. London: Bloomsbury Academic.

[8] Williamson, B. 2005. "What are multimodality, multisemiotics and multiliteracies?--- A brief guide to some jargon.” NESTA Futurelab http://www.futurelab.org.u/viewpoint/arr49.htm.

$[\mathrm{EB} / \mathrm{OL}]$.

[9] Hu, Z. (2007). Multimodality in Social Semiotics Research. Language Teaching and Research, (1).

[10] Suhor, C. 1984. Towards a semiotics-based curriculum [J]. Journal of Curriculum Studies, 16, 247-257.

[11] Gu, Y. (2007). Analysis of Multimedia and Multimodal Learning. Foreign Language E-learning Teaching, (2).

[12] Zhang, D.(2009). Exploring the Comprehensive Theoretical Framework of Multimodal Discourse Analysis. Chinese Foreign Languages, (1). 
[13] Stein, P. (2000). Rethinking Resources: Multimodal Pedagogies in the ESL Classroom. TESOL Quarterly, (34).

[14] Liu, X. (2012). Investigation and Analysis of College English Audiovisual Teaching from the Perspective of Multimodality. Exams and Evaluations: College English Teaching and Research Edition, (3).

[15] Huang, X. (2011). Cultivation of College Students' Multiple Reading Ability in Multimodal Teaching Mode Research. Higher Education Research in Southwest University of Science and Technology, (9).

[16] Kao, S., and O'Neill, C.(1998). Words into worlds Learning a second language through Process Drama. London: Ablex Publishing.

[17] Bolton, Gavin. (1992). New perspectives on classroom drama. Hemel Hempstead: Simon \& Schuster Education.

[18] Bolton, Gavin. (1998). Acting in classroom drama a critical analysis. London: Trentham Books.

[19] Bolton G. (2007). A History of drama education. A search for Substance. International handbook of research in arts education. Ed. Bresler L. Springer International Handbooks of Education, Vol. 16.

[20] Neelands, J. (1984). Making sense of drama. A guide to classroom practice. Oxford: Heinemann Educational Book.

[21] Booth, D. (2005). Story drama: Creating stories through role playing, improvising, and reading aloud. 2nd ed. Markham, UK: Pembroke Publishers.

[22] Edmiston, B., and P. Enciso. (2002). Reflflections and refractions of meaning: Dialogic approaches to classroom drama and reading. In The handbook of research on teaching and the English language arts, ed. J. Flood, D. Lapp, J. Squire, and J. Jensen, 868-80. New York: Simon \& Schuster Macmillan.

[23] Wilhelm, J. D., and B. Edmiston. (1998). Imagining to learn. Portsmouth, NH: Heinemann.

[24] Byram, M., and M. Fleming, eds. 1998. Language learning in intercultural perspective: Approaches through drama and ethnography. New York: Cambridge University Press.
[25] Culham, C. (2002). Coping with obstacles in drama-based ESL teaching: A nonverbal approach. In Body and language. Intercultural learning through drama, ed. G. Brauer. Westport, CT: Ablex Publishing.

[26] Holden, S. (1981). Drama in Language Teaching. Harlow: Longman Group, United Kingdom.

[27] Mackey, S., and S. Morrison. (2014). Drama Teachers: Global Encounters. Research in Drama Education: The Journal of Applied Theatre and Performance, 19 (4): 366-372.

[28] Nicholson, H. (2011). Expert Interview with Helen Nicholson Editor of RiDE: The Journal of Applied Theatre and Performance. London: Taylor \& Francis.

[29] Davis, S. (2015) Drama, education and curriculum: alive, kicking and counting, Research in Drama Education: The Journal of Applied Theatre and Performance, 20: 3, 327-330.

[30] Wang, W.-J., T. Po-Chi, B. J. Kim, and H. L. Kok. 2013. "New Imaginings and Actions of Drama Education and Applied Theatre in NIE4 in Asia." Research in Drama Education: The Journal of Applied Theatre and Performance, 18 (1): 79-93.

[31] Kavakli, N. (2016). A gimmick for mimmick: the ELF student-teachers' attitudes towards drama course. International Online Journal of Education and Teaching, 3 (2), 122-130.

[32] Connelly, M., \& Clandinin, J. (2006). Narrative inquiry. In J. Greeni, G. Gamilli, \& Elmore (Eds.), Handbook of Complementary Methods in Education Research. Mahwah, NJ: Erlbaum.

[33] Chen, Y. (2019). Enhancing EFL Students' English competence Through Drama: A Case Study in a Primary School in China. English language teaching, (6), 68-74.

[34] Chen, Y. (2014) Cultivation of Multiliteracies Ability of Freshmen in Multimodal Perspective: An Empirical Study of EFL Teaching in English News. Overseas English, (6).

[35] Corbin, J., \& Strauss, A. (2015). Basics of qualitative research: Techniques and procedures for developing Grounded Theory (4th ed.). Thousand Oaks: Sage. 